\title{
PERTANGgUNGJAWABAN PIDANA PADA ANAK TERHADAP PELANGGARAN LALU LINTAS YANG MENYEBABKAN KEMATIAN
}

\author{
I Made Dwi Satya Anggara, A.A Sagung Laksmi Dewi, Luh Putu Suryani \\ Fakultas Hukum Universitas Warmadewa, Denpasar-Bali, Indonesia
}

\begin{abstract}
Abstrak
Belakangan banyak terjadi kasus pelanggan lalu lintas yang dilakukan oleh anak-anak. Hal tersebut sangat menghawatirkan karena tidak jarang pelanggaran lalu lintas menyebabkan kecelakaan hingga timbul korban meninggal. Tidak hanya itu permasalahan juga timbul dari segi tanggungjawab anak, dalam hal ini jika terjadi korban meninggal dari pelanggaran lalu lintas yang dilakukan anak. Tujuan penelitian ini ialah untuk menganalisis tanggungjawab anak terhadap pelanggaran lalu lintas yang menimbulkan korban meninggal. Metode yang digunakan dalam penulisan skripsi ini ialah bahan hukum primer. Berdasarkan penelitian yang dilakukan ditemukan bahwa usia anak sangat menentukan dalam menjatuhkan hukuman kepada anak. Anak yang berusia di bawah empat belas tahun hanya bisa dikenakan sanksi berupa tindakan dan sanksi berupa pidana dikenakan pada anak berusia di atas 14 tahun hingga 18 tahun sesuai batas usia anak menurut peraturan perundang-undangan yang berlaku. Ketentuan sanksi pidana penjara terkait tanggungjawaban terhadap tindak pidana yang dilakukannya telah diatur dengan berdasarkan ketentuan hukumannya $1 / 2$ dari maksimal ancaman hukum untuk orang dewasa sesuai dengan peraturan perundang-undangan yang mengatur tentang peradilan anak.
\end{abstract}

Kata Kunci: Anak; Lalu Lintas; Pertanggung Jawaban Pidana; Pelanggaran

\begin{abstract}
Lately, there are large number of children who often commit criminal traffic violations. It is truly alarming as it is uncommon to traffic violations to cause a crash to arise the victim died. Not only that, problems also arises in terms of responsibilities, in this case the victim died from a traffic offence committed. The purpose of this research is to analyse the responsibility of children against traffic offences which cause the victim's death. The method used in writing this essay is primary legal material. Based on the research conducted found that the age of the child greatly influences the overthrow of punishment on the child. Children aged under 14 years can only be charged penalties act whereas the provision of criminal sanctions is a child aged over 14 years to 18 years old according age limit child according to Act No. 35-year 2014 About child protection article 1 point 1. Provision of criminal sanctions of prison-related responsibilities against the crime that he had arranged with the penalty provisions based on $1 / 2$ (one-) maximum threat from adults in accordance to article 81 paragraph (2) of Act No. 11 of 2012 about the criminal justice system.
\end{abstract}

\section{Keywords: Child; Traffic; Criminal Liability; Offense}

\section{PENDAHULUAN}

Anak-anak adalah bagian yang tidak terpisahkan dari kelangsungan hidup manusia dan kelangsungan hidup suatu bangsa dan negara. Mengingat anak-anak memiliki peranan yang sangat penting, maka hak-hak anak-anak ini tertuang dalam konsitusi secara jelas, yang menyatakan bahwa negara menjamin setiap anak hak untuk bertahan hidup, untuk tumbuh dan berkembang dan memiliki hak untuk dilindungi dari kekerasan dan diskriminasi.

Anak-anak yang merupakan bagian dari generasi muda biasanya menaruh perhatian yang serius pada masalah masyarakat, karena pada usia itu ide-ide mulai tumbuh, dimana anak-anak cenderung untuk mengharapkan kesempurnaan (Prinst, 2000). Sehingga menimbulkan perilaku yang tidak sesuai dengan peraturan dan melakukan penyimpangan-penyimpangan terhadap aturan-aturan yang berlaku. 
Di masyarakat penyelewenangan tersebut lazim disebut pelanggaran atau bahkan juga disebut sebagai kejahatan (Waluyo, 2004).

Proses dalam menegakan hukum dipengaruhi adnaya kesadaran dari masyarakat tentang hukum. Penegakan hukum akan mencapai hasil yang bnaik apabila diikuti dengan kesadaran yang tinggi dari masyarakat untuk tidak melakukan pelanggaran hukum. Namun demikian masih sering tejradi di masayrakat pelanggaran terhadap hukum, yang salah satunya adalah pelanggaran lalu lintas. Untuk mengatasi hal tersebut, peran pemerintah sangat penting dalam menanggulangi pelanggaran yang terjadi di jalan yang salah satunya adalah disebabkan oleh anak dengan memperbaiki sistem transportasi dan kendaraan umum sehingga anak-anak merasa nyaman untuk menggunakan kendaraan umum dalam melakukan aktivitasnya. Disamping itu, juga dapat mengurangi kemungkinan kecelakaan dan kemacetan di jalan raya. Selain itu, peran orang tua dalam mengawasi anak dalam menggunakan kendaraan bermotor juga berperan penting.

Sebagian besar masyarakat Indonesia masih memiliki kesadaran yang rendah dalam berlali lintas (Witono, 2014). Pelanggaran lalu lintas tidak hanya dilakukan oleh orang dewasa, anak di bawah umur juga melakukan pelanggaran lalu lintas, tidak sedikit dari pelanggaran ini yang mengakibatkan kematian. Proses anak-anak yang menghadapi hukum dimulai di tingkat polisi ketika penyidik kemudian melanjutkan tahap penuntutan yang dilakukan oleh jaksa penuntut anak dan melanjutkan proses penuntutan di pengadilan berdasarkan peraturan-peraturan yang berlaku. Pada tingkat investigasi, penuntutan dan pemeriksaan kasus anak-anak di pengadilan negeri harus mencari pengalihan atau diversi. Diversi dalah salah satu bentuk mediasi yang dilakukan untuk mendapatkan kedamaian dalam kasus anak-anak yang dihadapkan pada hukum kedua anak sebagai pelaku, korban dan saksi.

Seorang anak yang berhadapan dengan hukum menjalani proses dimulai dari tingkat kepolisian yang merupakan pejabat penyidik, lalu diikuti dengan tahap penuntutan oleh jaksa anak, selanjutnya dalam proses penuntutan di penagdilan dilakukan berdasakran peraturan perundangan yang berlaku. Dalam melaksanakan proses terhadap anak yang berhadapan dengan hukum, pihak berwenang wajib mengutamakan melalui proses diversi. Diversi merupakan salah satu bentuk mediasi yang dilakukan untuk mendapatkan perdamaian dalam kasus anak yang berhadapan dengan hukum baik anak sebagai pelaku, korban maupun saksi.

Kajian ini mengungkap tentang pertangguangjawaban pidana pada anak terhadap pelanggaran tindak pidana lalu lintas yang menyebabkan kematian dan bentuk Sanksi Pidana terhadap anak pelaku tindak pidana tersebut.

\section{METODE PENELITIAN}

Tipe penelitian dalam penelitian ini mengguankan tipe penelitian hukum normatif, yaitu dengan mengkaji peraturan perudnang-undangan yang berlaku. Sumber bahan hukum dalam penelitian ini adalah sumber bahan hukum primer dan sekunder. Teknik pengumpulan bahan hukum menggunakan teknik studi pencatatan dan studi dokumentasi. Analisis bahan hukum menggunakan analisis bahan hukum secara interpretasi hukum dan deskriptif.

\section{HASIL DAN PEMBAHASAN}

Pertangguangjawaban Pidana pada Anak terhadap Pelanggaran Tindak Pidana Lalu Lintas yang Menyebabkan Kematian

Tindak pidana adalah pelanggaran norma-norma dalam tindak hukum lain, yaitu hukum perdata, hukum ketatanegaraan, dan hukum tata usaha pemerintah, dimana oleh pembentuk undang-undang disebut dengan hukuman pidana (Wirjono, 1981). Moeljato menyebutnya dengan sebutan tindak pidana, yang merupakan perbuatan yang dilarang oleh peraturan perundang-undangan yang berlaku, dimana larangan tersbeut disertai dengan ancaman berupa sanksi, bagi siapa saja yang melakukan pelanggaran tersebut larangan-larangan tersbeut. Selain itu, perbuatan pidana juga dapat dikatakan sebagai perbuatan yang dilarang dan diancam dengan pidana, larangan tersebut ditujukan kepada perbuatan, yaitu suatu keadaan atau kejadian yang disebabkan oleh perbuatan orang, sedangkan ancaman pidananya ditujukan kepada orang yang melakukan perbuatan tersebut (Moeljatno, 1987).

Persimpangan lalu lintas di jalan meningkat dengan cepat, sehingga semua konsekuensinya juga harus ditanggung oleh masyarakat itu sendiri. Salah satu konsekuensi dari terjebak dalam kebingungan lalu lintas di jalan adalah kecelakaan lalu lintas. Jika dilihat dari asalnya, kecelakaan itu 
berasal dari kata celaka, yang berarti ia menderita sesuatu yang merepotkan, sial atau tidak bahagia. Pemahaman tentang kecelakaan lalu lintas sebagaimana dijabarkan dalam Prosedur Standar Operasional tentang Penanganan Kasus Lalu Lintas di Kepolisian Daerah Bali lalu lintas, yaitu, kecelakaan lalu lintas adalah peristiwa jalan yang tidak terduga dan tidak disengaja yang melibatkan kendaraan dengan atau tanpa pengguna jalan lain yang mengakibatkan korban manusia dan / atau kehilangan properti.

Tanggung jawab pidana mengandung asas kesalahan (prinsip culps), yang didasarkan pada keseimbangan monodualistik bahwa asas kesalahan berdasarkan nilai keadilan harus disandingkan berpasangan dengan prinsip legalitas berdasarkan nilai kepastian. Meskipun konsep ini didasarkan pada prinsip bahwa pertanggungjawaban pidana didasarkan pada kesalahan, dalam beberapa kasus tidak menutup kemungkinan pertanggungjawaban pengganti dan pertanggungjawaban yang ketat. Masalah kesalahan (error) adalah kesalahan tentang keberadaannya (error facti) atau kesalahan tentang hukumnya sesuai dengan konsep alasan memaafkan sehingga pelaku tidak dihukum kecuali kesalahannya yang harus disalahkan. Tanggung jawab pidana harus memperhatikan bahwa hukum pidana harus digunakan untuk mewujudkan masyarakat yang adil dan makmur. Hukum pidana digunakan untuk mencegah atau mengatasi tindakan yang tidak diinginkan, penggunaan fasilitas hukum pidana dengan sanksi negatif harus memperhatikan biaya dan kemampuan tenaga kerja dan lembaga terkait, sehingga tidak ada kelebihan beban dalam melaksanakannya.

Agar seseorang dapat dihukum dan sekaligus dapat memenuhi tuntutan terhadap keadilan dan kemanusiaan, maka harus ada perbuatan-perbuatan yang bertentangan dengan peraturan yang berlaku sehingga dapat dipermasalahkan kepada orang yang melakukan perbuatan tersebut. Syarat lainnya adalah orang tersebut adalha orang yang dapat dimintai pertanggungjawaban. Untuk setiap pelanggaran yang dapat dihukum, itu harus didasarkan pada hukum yang dibuat oleh pembentukan hukum dan pendapat umum tidak dapat menentukan selain dari apa yang telah ditetapkan dalam hukum. Definisi dalam arti luas lebih terfokus pada sifat melawan hukum dan pertanggungjawaban, yang merupakan elemen yang telah dirumuskan secara tegas dalam setiap pelanggaran atau elemen tersembunyi yang diam-diam dianggap ada. Batasan usia yang dapat idsebutkan sebagai anak secara nasional ditentukan menurut hukum pidana dan hukum perdata. Pengertian anak dituangkan dalam Konvensi Perserikatan Bangsa-Bangsa yaitu, anak-anak adalah setiap manusia yang berusia di bawah delapan belas tahun kecuali menurut hukum yang berlaku untuk anak-anak, kedewasaan tercapai sebelumnya.

Seorang anak di bawah umur dapat dimintai pertangungjawaban atas kejahatan yang dilakukannya dengan melakukan proses secara terpisah dan tidak sama dengan proses pertanggungjawaban pada orang dewasa, hal ini ditentukan berdasarkan peraturan perundangundangan yang berlaku yang dilaksanakan berdasarkan prinsip, perlindungan, keadilan, nondiskriminasi, kepentingan terbaik anak-anak, penghormatan terhadap pendapat untuk anak-anak, kelangsungan hidup dan pertumbuhan anak-anak, bimbingan dan bimbingan anak-anak secara proporsional, perampasan kebebasan dan hukuman sebagai upaya terakhir, dan menghindari pembalasan.

Dalam hal pertanggungjawaban pidana terhadap anak di bawah umur diatur dalam peraturan yang berlaku di Indonesia yaitu KUHP dan di luar KUHP. Dalam mempertangugngjawabkan tindakannya, didasarkan pada prinsip yang berkaitan dengan pertangung jawabna pidana yaitu dalam bentuk prinsip-prinsip legalitas, dan prinsip kesalahan, karena Andi Hamzah telah mengutuk pendapat Pompe dan Jonkers, termasuk "melawan hukum" sebagai berbasis kesalahan "disengaja". "Atau" salah "(schuld) dan dapat dipertanggungjawabkan (toereke ningsvatbaar heid) atau istilah pompe toerekenbaar (Hamzah, 2010).

Beberapa peraturan khusus anak yang menjadi landasan pencari kebenaran dan keadialn bagi anak di bawah umur yang didasarkan pada hukum mateiril. Karena itu hakim harus memerhatikan dan mengkaji isi dari surat dakwaan jaksa penuntut umum kemudian akan dibacakan dalam proses pra peraidlan dengan yang didasarkan pada unsur-usnur pasal yang dijadiakn dakwaan dan putusan yang dibuat oleh jaksa penuntut umum. Untuk dapat dikategorikan seorang anak memiliki unsur-usnur tindak pidana atua tidak, dapat dilihat dari aspek-aspek sebagai berikut:

1. Aspek kemampuan seorang anak yang melakukan tindak pidana untuk mempertanggungjawbakan perbuatannya, yang berarti bahwa anak telah memenuhi syarat 
untuk kriteria usia seorang anak diatur dalam peraturan yang mengatur tentnag peradilan anak.

2. Unsur pertanggungjawaban pidana, yang berarti lebih ditekankan pada unsur kesalahan yang merupakan unsur penting dalam tindak pidana yang dapat digunakan untuk menentukan seorang anak dapat dipidana ataupun tidak.

3. Pembuktian yang dilakukan berdasarkan temuan-temuan bukti bahwa anak melakukan pelanggaran yang akan dipaparkan di depan pengadilan.

\section{Bentuk Sanksi Pidana Anak terhadap Pelanggaran Tindak Pidana Lalu Lintas yang Menyebabkan Kematian}

Sanksi pidana merupakan pemberian hukuman yang bersifat penderitaan dan penyiksaan. Pernyataan ini selaras dengan pendapat Anselm Von Feuerbach yang tekrenal dengan ajarannya tentang "Tekanan Psikologis" (de psychologiesche dwang), yaitu ancaman hukuman akan mencegah orang lain melakukan kejahatan (Kartanegara, 2001).

Memberikan hukuman atau sanksi dan proses hukum yang terjadi dalam kasus-kasus pelanggaran hukum yang dilakukan oleh anak-anak memiliki perbedaan terhadap kasus pelanggaran hukum yang dilakuan oleh orang dewasa, karena alasan pemberian hukuman yang dilakukan oleh negara adalah bahwa setiap warga negara adalah orang yang bertanggung jawab dan mampu menjelaskan semua tindakannya. Sedangakan seorang anak dianggap sebagai seseorang yang belum mampu sepenuhnya bertanggungjawab atas tidnakan yang dilakukan. Untuk itu anak-anak yang melakukan pelanggaran harus mendapatkan pelrakuan yang khusus yang berbeda dari perlakuan terhadap oragn dewasa.

Berkaitan dengan pemberian sanksi kepada seorang anak, karena itu penting untuk mengetahui bahwa seorang anak belum mencapai usia dua belas (12) tahun, tidak dapat diajukan sebelum persidangan anak, meskipun tidnakan kejahatan telah dilakukan oleh seorang anak (Prakoso, 2018). Hal ini didasarkan pada pertimbangan sosiologis, psikologis dan pedagogis, bahwa seorang anak yang belum berusia 12 (dua belas) tahun belum dapat menjelaskan dan mempertanggungjawabkan tindakannya (Prakoso, 2018). Seorang anak yang melakuakn tidnak pidana tidak dapat dikenakan sanksi atas tindakan yang dilakukan selama anak belum berusia dua belas tahun. Untuk menentukan sanksi atas tidnakan yang dilakukan oleh anak di bawah umur, seorang hakim mempunyai hak untuk menentukan tingkat pelanggaran pidana yang dilakuan anak di bawah umur.

Selain itu, menurut Walahe, untuk dapat menentukan seorang anak akan dikenakan hukumanatas kejahatan yang dilakkannya, seorang hakim mempertimbangkan beratnya tindak pidana yang dilakukan. Selain itu, kondisi anak, dan orang tua atau wali juga perlu diperhaitkan selain itu hubungan antara anggota dan keluarga serta lingkungan juga perlu mendapatkan perhatian (Walahe, 2013).

Di dalam meberikan sanksi keapda anak yang berusia di bawah umur, perundang-undangan dengan ketnetuan seorang anak di bawah umur belum dapat dikenakan sanski, sedangkan menurut kenteentuan sanksi pidana diberikan kepada anak berdasarkan usia di atas empat belas tahun hingga delapan belas tahun. Namun, telah diatur dalam peraturan perundangan yang berlaki terkait dengan sanksi dan sanksi pidana dalam ketentuan keparahan keputusan hakim dalam menjatuhkan hukuman, seperti yang dijelaskan dalam Pasal 70 "Ringannya tindakan, situasi pribadi anak, atau keadaan ketika suatu tindakan diambil atau dapat digunakan sebagai dasar untuk pertimbangan hakim untuk tidak menjatuhkan sanksi pidana atau mengambil tindakan dengan mempertimbangkan aspek keadilan dan kemanusiaan ". umur seorang anak adalah sangat penting diperhatikan dalam proses perkara pidana, dalam menentukan sanksi yang akan diberikan sebagai bentuk tanggung jawab bagi anak, serta usia anak sebagai patokan yang disebut sebagai anak atau tidak. Mengeai pemberian sanksi pinalti, yang ditentukan dalam peraturan perundangan yang berlaku, menggambarkan penetapan sanksi bagi anak di bawah umur, yaitu berupa sanksi tindakan dan sanksi pidana.

Selain sanksi pidana yang dikenakan pada anak di bawah umur, sleanjutnya dijelaskan sanksi yang kedua, yaitu sanksi tidnakan terhadap anak di bawah umur. Dimana sanksi tindakan sudah diatur dalam peraturan perundang-undangan tentang anak, seorang anak di bawah umur yang melakukan pelanggaran diberikan tidnakan yang dapat dikenakan kepada anak antara lain:

a. Mengembalikan anak pada keluarga 
b. Menyerahkan anak pada seseorang

c. Memberi perawatan di rumah sakit jiwa

d. Merawat di LPKS

e. Mewajiban anak untuk mengikuti pendidikan formal dan pelatihan yang diselenggarakan pemerintah maupun pihak swasta

f. Melakukan pencabutan terhadap surat ijin mengemudi serta

g. Memperbaiki akibat dari tindak pidana yang dilakukan

Pengenaan sanksi tindakan terhadap anak di bawah umur telah dijelaskan dalam peraturan perundangan yang berlaku dimana sanksi dikenakan paling lama satu tahun, perundangan lain juga mennetukan dikenakan sanksi tindakan dengan penjara paling singakt 7 tahun.

\section{SIMPULAN \& SARAN \\ Simpulan}

Pertanggungjawaban pidana pada anak terhadap pelanggaran lalu lintas yang menyebabkan kematian, serta beberapa bentuk sanksi yang dapat di terapkan. Seorang anak dapat dapat mempertangugngjawbakan perbuatan yang dilakukan didasakran pada ketentuan usia anak tersebut, sebagaimana yang diatur dalam ketentuan sistem peradilan pidana anak, yang mengatur tentang pemberian sanksi berdasarkan ketentuan usia anak, yaitu berumur dibawah 14 tahun hanya dapat dimintai pertanggungjawaban berupa tindakan sesuai pasal 69 ayat (2) yaitu: mengembalikan kepada keluarga, menyerahkan kepada seseorang, merawat anak di rumah sakit jiwa, merawat di LPKS, wajib melakukan pendidikan formal serta pelatihan yang dilaksanakna oleh pemerintah maupun swasta, pencabutan surat izin mengemudi, perbaikan akibat tindak pidana. Berdasarkan ketentuan sanksi pidana penjara dari sanksi pidana pokok di atas bahwa terkait dengan pertanggungjawaban anak terhadap kecelakaan yang menyebabkan kematian, anak tersebut hanya dapat diancam maksimal 1/2 (satu perdua) dari ancaman pidana penjara orang dewasa.

\section{Saran}

Seharusnya semua pihak harus ikut serta dalam malasah penangannan pelanggaran lalu lintas yang di lakukan anak, tidak hanya itu anak seharusnya mendapatkan pemahaman terlebih dahulu mengenai tata tertib lalu lintas agar tidak terjadinya pelanggaran lalu lintas apalagi yang mengakibatkan kecelakaan. Hal tersebut akan lebih membentuk karakter generasi penerus bangsa yang tertib akan peraturan khususnya dalam bidang lalu lintas.

\section{DAFTAR PUSTAKA}

Hamzah, A. (2010). Hukum Acara Pidana Indonesia. Sinar Grafika.

Kartanegara, S. (2001). Hukum Pidana Bagian Satu: Kumpulan Kuliah. Balai Lektur Mahasiswa.

Moeljatno. (1987). Azas-azas Hukum Pidana. Bina Aksara.

Prakoso, A. (2018). Pengantar Hukum Indonesia. Laksbang Pressindo.

Prinst, D. (2000). Hukum Anak Indonesia. PT. Citra Aditya Bakti.

Walahe, S. (2013). Pertanggungjawaban Pidana dari Anak di Bawah Umur yang Melakukan Pembunuhan. Lex Crimen, 2(7), 43-52.

Waluyo, B. (2004). Pidana dan pemidanaan. Sinar Grafika.

Wirjono, P. (1981). Asas-asas Hukum Pidana di Indonesia. Eresco.

Witono, H. Y. (2014). Undang-undang Lalu Lintas \& Aplikasinya. Dunia Cerdas. 